\title{
Legal Protection for Buyers in Buying and Selling with Counterfeit Certificate Object
}

\author{
Putu Satria Fajar Purwanta*, I Made Suwitra, I Ketut Kasta Arya Wijaya \\ Master of Law, Universitas Warmadewa, Denpasar-Indonesia \\ Email: *satria.purwanta16@yahoo.co.id
}

Published: 30/09/2021

How to cite (in APA style):

Purwanta, P. S. F., Suwitra, I. M., \& Wijaya, I. K. K. A. (2021). Legal Protection for Buyers in Buying and Selling with Counterfeit Certificate Object. Jurnal Hukum Prasada, 8(2), 136-144. doi: https://doi.org/10.22225/ jhp.8.2.2021.136-144

\begin{abstract}
The lack of precision between the buyer and the land deed official is a factor in the emergence of the uncertainty of the law against the certificate issue. In addition, the seller also intentionally does not notify that there is a defect in the certificate that causes the buyer to suffer a loss. It needs the protection of the buyer acting in good faith so that in the future no longer appears dispute regarding the certificate of a double or false which is used as the object of buying and selling. This study aims to know the certainty of the law, the transfer of rights over the land and the form of the legal protection of the buyer acting in good faith in buying and selling with counterfeit certificate object. The method used in this study is normative legal research. In addition, the legal materials are obtained by using a literature study. The results of this study showed that the transfer of rights over the counterfeit certificate object causes legal uncertainty because there is a violation of article 1320 of the Civil Code, namely the agreement and skills that can be requested for cancellation, the form of the legal protection of the buyer acting in good faith in the form of protection repressive where such protection can be provided in the form of criminal sanctions, administrative and civil to the seller.
\end{abstract}

Keyword: Counterfeit Certificate; Good Faith Buyers; Legal Protection.

\section{INTRODUCTION}

The land is very important for human life because it has many benefits so that humans always try to control the land. One of the efforts that humans can make is by buying and selling. Land tenure has been attempted as optimally as possible to improve the standard of living of every human being. To accommodate the ownership of land rights, a law that regulates agrarian matters was enacted, namely Law Number 5 of 1960 (Siahaan, 2003:1-3). Land rights in the law can be given to the good people of that alone or jointly or a legal entity. Land rights given by the law can be divided into two, namely sourced on the Rights of the Nation is what's called the Rights of the primary one of which is a Property Right, while the special rights come indirectly from the rights of the nation or secondary property rights (Permadi, 2016).

To provide legal certainty for the owner of the land rights, by the Basic Agrarian Law Act, as mentioned, can only be obtained through the procedure of land registration. Proof of registration of land is in the form of a certificate (Rashid, 1987:45). The rampant development in the era of industrialization is resulting in the transaction of sale of land is increasing. So that later sell-buy can be said to be valid it is necessary the presence of a sale and purchase agreement. Often in the sale and purchase, the buyer selling the goods without known whether the seller is the owner of the goods or not, as against the goods move there is a principle, those who master the material move is considered as the owner. The seller should provide an explanation in advance about the deed as the object of sale 
and purchase that the deed is protected from any interference, but here the seller deliberately does not inform the buyer about the deed as the object of the sale and purchase, in addition, the seller also includes false information in the certificate so that the seller's actions also include an element of fraud so that buyers who have good intentions often suffer losses even though later it is known that the seller's lies have been committed. A sale and purchase agreement made by a buyer in good faith is included in the realm of civil law.

Buyers who have good intentions provide trust from the opposite party, namely the seller. According to the buyer, the seller here is a person who speaks according to the facts and there are no hidden lies in the agreement that can cause the buyer to suffer losses. According to Article 1338 paragraph (3) of the Civil Code, good faith is very important to put in an agreement, it is intended to provide a safe and convenient for each party. If good faith is dispensed then the buyer who is acting in good faith can be given protection and the covenant made can be considered valid. Therefore it is necessary to include the role of government in addressing the case of buying and selling with counterfeit certificate object this so will be able to provide legal certainty on the land certificate is used as the object in the buy and sell and to give legal protection to the buyer acting in good faith that the right was taken by the seller.

There are some similar studies conducted by some researchers previously that examined legal protection for buyers in buying and selling with counterfeit certificate object. Eleanora \& Sari (2019) in their study conducted Good Selling Buying Agreement and Legal Protection for Sellers. The results of their study showed that the behavior of the party implementing the agreement and the assessment must also be based on rationality and propriety. The parties make the agreement at least have a good intention so that the agreement can be carried out with the principle of propriety, justice and legal certainty. Putra (2020) in his study The Basics of Good Faith and Good Intention in Land Purchase System in Indonesia, showed that the legal protection for buyers of land rights in good faith, that buyers as parties in good faith, get legal protection. The form of legal protection can be preventive legal protection and repressive legal protection. Another similar study also conducted by Suparwadi et al. (2020) that examined Legal Protection against Buyer in Good Faith on Dual-Certified Land revealed that BPN in issuing the certificate refers to the Government Regulation No. 24 of 1997 on land registration and BPN is not able to detect the possibility of data manipulation by the applicant because BPN has no obligation to do materially check the application data for certificate issuance. In addition, BPN gives false information to the land related to the soil that will be the object to buy and sell as a result of not being coordinated between the ruling on the court with BPN related to the land matter and the form of administrative liability of BPN, namely the accountability of the Administration (Condemnatoir) or the creation (constitutive). Based on the previous studies above, it can be stated both the buyer and the seller must have the same legal protection if both parties have good faith. Therefore, based on the background and the previous studies above, this study aims to know the certainty of the law, the transfer of rights over the land and the form of the legal protection of the buyer acting in good faith in buying and selling with counterfeit certificate object.

\section{METHOD}

The method used in this study is normative legal research. In addition, normative legal research is legal research that uses the law as a basis to analyze a problem; the norms contained in the law can assist in the resolution of problems such as laws. The legal approach used in this study is the legislation approach (statute approach), analytical approach, and case approach. The legislation approach (statute approach) was conducted by reviewing all laws and regulations relating to the legal issues that are being discussed. The analytical approach is an approach to understand the term contained in the existing regulations. Meanwhile, the case approach is an approach that is carried out by way of review of cases related to the issues faced which have become the court decisions that have permanent legal force. The technique of collecting legal materials used is the card (card system), where this technique uses three legal materials, namely primary, secondary 
and tertiary. Those three legal materials are put together and documented as well as recording through the file system. A variety of sources in the study of literature in the form of an assortment of books in perspective of the normative as the materials are used to analyze and provide a discussion of the problems in this research.

\section{RESULT AND DISCUSSION}

\section{Legal Certainty, the Transfer of Rights over the Land with Counterfeit Certificate Object}

In Article 1320 of the Civil Code are the terms of the purchase agreement that must be fulfilled in order to be able to provide the legal certainty of the sale and purchase agreement made by the seller with the buyer (Hernoko, 2014:157). Article 1320 of the Civil Code explains some terms that should be done by the parties to an agreement:

The absence of a deal for those who book an appointment;

The ability of each party in the conduct of an agreement;

A subject-specific;

A cause that is not prohibited.

These elements, if not held with the right to have legal effect. There are some elements of the subjective condition in an agreement that is related to a person entitled to perform the agreement is good that a buyer or seller, please be aware that the party is not in remission so that the parties can make decisions, in addition, pronounce the word agreed to see whether there is an element of fraud in the agreement that will not harm the buyer. The legal consequences if the subjective conditions are not met by each party in making an agreement, the cancellation of the agreement can be requested. The cancellation is intended so that this agreement does not continue because it can cause loss to one of the parties to the agreement. This cancellation can be done by parties who have the right to cancel. This cancellation is also called the Cancellation of the Relative. The cancellation of the relative is divided into two: (Prodjodikoro, 1993:121)

Cancellation of a desire by certain parties that are conducted through a lawsuit to the court so that the judge can give the nullification of the agreement. As stated in article 146 of the Civil Code;

The cancellation of the next, through the decision of the judge that contains about the cancellation against the agreement. As stated in Section 1449 of the Civil Code.

The subjective condition that is not met results in the agreement can be requested for cancellation. The parties objected to the agreement whether it is the family, guardian and/or custodian. Cancellation by the interested parties needs to be requested clarification to determine whether the requesting cancellation is true people that have the right to do it and when it is known that party is not entitled to such agreement can still be implemented and the agreement binds both parties to the agreement. Cancellation of the agreement such as the above is included in the cancellation of the relatively (Adjie, 2011:65).

In making a covenant, the objective requirement is one of the requirements that must be met and when not met will cause legal consequences in the form of agreements made are experiencing null and void. Null and void is not necessary based on the request of both parties, because it automatically agreement that has violated the terms objective will be deemed not to exist and will not be binding on both parties making the agreement. The elements contained in the terms objective has been listed in Article 1320 of the Civil Code which regulates the terms of the validity of a treaty is the object that is used as the object of buying and selling. The obscurity of the object in the sale and purchase can be seen from the description of the object the less, causing doubts about the object other than the object that violates the existing rules that resulted in the emergence of criminal sanctions. For example, the agreement to use the object form of the drug, the drug is prohibited items for sale and therefore selling the drug null and void. Cancellation to buy sell can be called also with the cancellation of the absolute.

According to Bachsan Mustafa, positive law is made by the government to provide a 
guarantee in the form of legal certainty to the people. Legal certainty has three objectives, namely:

Uncertain about the legal rules made by the government.. the law.

Sure of the legal position these so that there is no overlap in the implementation of

Prevent arbitrary action by an individual who is not responsible for the cause not the fulfillment of the rights to which is owned by the subject of the law.

Legal certainty is a provision or provisions had long since written where the guidelines in the making of rule-other rules so that it can provide the direction and guidance of the public in the act. Since written and endorsed as a rule then the law can provide legal certainty.

In the Judgment of the District Court of Denpasar No. 505/Pid.B/2020, the seller has committed an offense against the two terms of the agreements listed in Article 1320 of the Civil Code, namely agreed for those who bind themselves and their skills in a treaty. There is an element of fraud in a certificate is because the information contained in the certificate is false does not fit the reality, which is where the description that the seller is the children of Men Pugih (Heir) is false information because once checked in Card Family owned by the Men Pugih behalf of the Seller (I Made Wisnawa) is not listed so that the sale and purchase agreement does not meet the elements of a deal. A skill that is derived from the word competent means could or can do something; the seller (I Made Wisnawa) should not be able to buy or to sell the land due to the seller not being included in the heir of this land. Authority in the sale and purchase of this should be given to the heir to the original from the ground within About Pugih. By not meeting the subjective condition that is listed in Article 1320 of the Civil Code then in-between land with the counterfeit certificate object does not provide legal certainty, as a result of sale and purchase agreement can be requested for cancellation.

In an agreement, in addition to legal certainty, justice must also be fulfilled. According to John Rawls, in making an agreement, bad deeds cause harm to one party for the greatest benefit. This attitude is contrary to the principles of justice, where justice wants that there are equal rights and obligations by each party, it is intended that each party can feel the advantage in the conduct of the sale and purchase agreement and no one feels aggrieved from the results of this agreement. Consideration of the advantages to each of the parties to note that each of the parties gets an equal opportunity to earn a profit. These considerations should be based on the benefits to be achieved and the right as to what should be owned by each party. Only with that justice as fairness can be enjoyed by all, in which case it should be understood that the concept of similarity according to John Rawls as "equality of status and rights", obtained all the people. Therefore, it should be understood that justice does not always mean the same amount, regardless of differences that objectively exists in every individual person (Adjie, 2011:75).

The presence of Justice is here to be one of the basic values that can be beneficial to both parties. Justice is defined as the division of the same average so that each party can feel their rights and obligations. In the case of sale and purchase with counterfeit certificate object, the seller already has the intention to get the benefit, so as to facilitate the action of the seller intentionally put false information in the certificate, which in turn is trusted by buyers that the correct certificate is owned by the seller, so that there is inequality of rights and obligations owned by the seller and the buyer, the buyer's obligation is to notify the buyer in advance of the state of the goods next once everything is known by the buyer, the seller is obliged to guarantee the goods is free of defects that the buyer is satisfied with goods sold by the buyer and the buyer can be avoided from the loss but the buyer has fulfilled its obligations, i.e. paying the cost of the transfer of rights over the land in accordance with the agreement, the seller to get the right form of money that has been paid by the buyer but the buyer did not get the right form of certificate of land rights that the original cause is not the achievement of justice in this purchase. As a result of the seller, the buyer suffered a loss which is quite a lot. 
In the sale and purchase of land, it is important to note that the land has been having a certificate or not, that can later be known to the rightful owners of this land. To certify the agreement of sale of land necessary evidence in the form of the deed of sale (deed of sale) made by parties who are appointed by the government, in this case, is the Official Land Deed or can be called by the Land Deed Official. The provisions of the Land Deed Official as the competent authority in issuing the certificate listed in Article 37 paragraph (1), PP 24 of 1997 on land registration. The deed of sale is in addition to functioning to explain that there has been a transfer of rights over the land, in addition as a condition in the process of registration of land in the National Land Agency. Article 19 paragraph (2) of the Basic Agrarian Law Act explained that in the conduct of registration of land, there are a series of activities to register the deed of sale in order to be a certificate of land rights and when all the process is already completed then it can be given a certificate of land rights as evidence of land ownership. In the certificate of land rights are letters measure or an image of the situation to explain the characteristics of the soil are then merged into a single unit and was given an endorsement by the Minister of Agrarian Affairs/Head of National Land Agency (Hartono, 2015:37).

A certificate is referred to as the original certificate if he has met the statutory provisions in both the formal and material. The strength of the evidence contained in the contents of the description is valid as truth for anyone and the person whose name is listed in the deed. The presence of evidence in the form of a certificate upon the land was intended to provide a safe and comfortable in sale and purchase of land, through the Law of the Land, namely the Basic Agrarian Law Act provides benefits in the form of legal certainty on the buyer. Based on the theory of benefits that are presented by Jeremy See, the law was solely to provide the benefit of happiness as possible for as many citizens of the community. The law of the Land here is present to provide benefits to the community especially in the sale and purchase of land. Passing this law between the seller and the buyer know about the procedure validity of the purchase agreement itself so as not to harm one of the parties. This course provides protection against the buyer acting in good faith because the buyer has already put a great deal of trust to the goods sold by the seller, especially for buyers who still lay with the sale and purchase of this land, so that if they find the issue related to the sale and purchase, the buyer can sue the seller so that the rights that they can be protected and the seller can fulfill the rights that should be obtained by the buyer. The buyer In the agreement of sale of land is very much found the problem, especially the contents of the certificate that is not in accordance with the state of the original. The act has certainly carried the seller to make a profit by improper means. Good faith can be used as a reason to protect the parties in legal action.

The implementation of the decision of the District Court of Denpasar No. 505/ Pid.B/2020 against the sale and purchase disputes with counterfeit certificate objects is in the sale and purchase of necessary caution and precision and see on the certificate which is used as the object in the sale and purchase of land. Sell-buy the object is usually the procedure of the purchase is not as easy as buying goods that are categorized moving objects, because land is an object that usually still has customary values, therefore the land is specifically regulated in the BAL. Terms of materiel and the terms of the formal must be met when making the purchase agreement, it is intended that the sale and purchase agreement is recognized and has legal certainty. Such material conditions must be paid off from the selling price, while the two conditions are not or are not fulfilled, then the binding sale and purchase contract is usually used as the grounding for the commencement of buying and selling and the sale and purchase is used as a preliminary agreement while waiting for the fulfillment of the conditions. -The main terms of the agreement are selling before the Land Deed Official. The terms of the formal agreement of sale of land can be met by way of a sale and purchase agreement before the Land Deed Official so that it can be issued a deed of agreement which is used as an ingredient in registration.

The presence of jurisprudence explains that the act of the seller has been very detrimental to the buyer, the judge in giving attitudes and discretion is very appropriate so that the value of law and justice has been given in this ruling, the judge also been basing its decision upon the "propriety" and "protection of the public interest". Proven with the use of 
Article 266 of the criminal code that set about fraud, the seller has already proven to commit fraud that causes the buyer to experience loss, so as a result the seller is sentenced to imprisonment. Because the act already giving rise to the loss, the buyer is obliged to reimburse the costs already incurred by the buyer with reference to Section 1246 of the Civil Code. The granting of such damages may be given by way of filing a civil lawsuit to the District Court. The use of the article above can make the defendant receive punishment according to the act committed.

\section{Legal Protection for Good faith Buyers}

In a purchase transaction, good faith is very important because if the buyer has good faith in making a purchase, he will be protected by law. With the protection of the law against the buyer acting in good faith then the consequences are the sale and purchasing is legitimate. The Supreme Court either in the decision and also in a Circular has confirmed this, as in the Supreme Court Decision No. $251 \mathrm{~K} / \mathrm{Sip} / 195825$ August 1958 the traditions of the ruling reads: "Buyers who have been acting in good faith should be protected and buy that concerned should be considered legitimate".

In an agreement, an agreement made by both parties to create legal consequences in the form of rights and obligations that must be met by each party and if not met to make one of the parties can be given sanctions and the agreement can be cancelled. The seller and buyer had the necessity to comply with the obligations described in the agreement so that the arising of justice in the agreement. So in making a treaty each party has a role to play in the one side of the debtors is a party that should do the fulfillment of the contents of such agreements while the creditor is the party that has the right to receive the contents of the agreement (Muljadi \& Widjaja, 2008:92).

An obligation for the buyer to check the first things related to the soil to purchase as well as about ownership. The buyer has the obligation to see and assess whether the land purchased is free from defects (not being pledged as collateral), in addition, it should be seen whether the seller is the owner of the land in accordance with that recorded in the certificate. The buyer must also obtain a description of the BPN about the land. If everything has been proved to be free from defects then sell-buy made in accordance with the provisions of the legislation, which is done by making a Deed of Sale before the Land Deed Official. Thus, it was only the buyer can be said to have good faith. According to the Supreme Court Circular No. 4 Year 2016 should the buyer could assess whether the sale that there is a defect or whether the seller is a person who is entitled to sell. Then if it is found that there are defects in the object of sale and purchase or the selling is not the person who has the right, but buyers still buy the land, then it can be interpreted that the buyer does not have good faith or the buyer malice. If the buyer malice, then if required by third parties may be at risk of the sale and purchasing cancelled by the court and will lose ownership of the land he bought.

In providing a sense of security and comfortable against the buyer, the seller should have the honesty to do with how to give a full description and details about the goods that are used as the object of buying and selling. The object of sale and purchase which has guaranteed the security and authenticity are expected not to cause such losses do not cause any harm to the buyer. Buyer should also have the initiative to examine the object that can be done with a way to check via the internet or ask the object to the experts, it aims to avoid the defects are not known and later is found then the sale and purchase can be cancelled. According to article 1338 paragraph 3 of the Civil Code, the agreement should be based on the good faith of each of the parties, good faith is very important in the sale and purchase is for the sake of giving a sense of security for each party. In good faith, it provides confidence to each party that the seller and buyer are the people who have the right to carry out the agreement, besides that the object of the agreement is protected from defects and disturbances, which is not suspected. The buyer acting in good faith need not worry when the seller will have that is not good faith in carrying out the agreement, as the buyer acting in good faith may be granted legal protection if the buyer already meets the criteria of the buyer acting in good faith (Rijan \& Koesoemawati, 2009:8).

Based on Article 1365 civil code, every act that violates the law and bringing losses to 
other people, obliging the person who provoked the loss was his fault to replace such losses. There are four requirements to determine an action to be qualified as an Act Against the Law: (Agustina, 2003:117).

Contrary to the obligations of the law the offender;

Contrary to the right of the subjective other people;

Contrary to morality;

Contrary to propriety, prudence and caution.

If an act does not meet the elements as specified in the article then the act cannot be said as an act against the law. Due to the actions of the seller in the sale and purchase has been qualified against the law then the seller must provide compensation for the losses incurred by the buyer. According to Taylor, the Protection of the Law is the act or attempt to protect society from acts arbitrarily by the ruler that is not in accordance with the rule of law, to realize the order and peace that allows man to enjoy his dignity as a human being (Setiono, 2004:3). According to Hadjon, legal protection can be divided into two, namely: the protection of the law of preventive and repressive legal protection.

Preventive legal protection is the protection of the law given by the government with the aim to prevent the occurrence of violations. Under Article 1491 of the Civil Code should the seller provide a complete explanation about the certificate that is used as the object of buying and selling, then dare to guarantee that the certificate does not contain defects and is free from other disorders that can later be detrimental to the buyer. But the fact that the seller does not give an explanation about the certificate, that the certificate is contained false information which is not in accordance with the facts of the original where the seller does not have the authority to sell the certificate is caused by the seller's name is not listed in the heir to the land so it can be concluded that the seller does not have proficiency in selling certificates such. The contents of the certificate can be said to contain elements of fraud. Furthermore, repressive legal protection is protection to resolve ongoing disputes. For example in the form of imprisonment, fines, restitution and additional penalties that will be able to make the perpetrator feel a deterrent. Associated with the protection of the law against the buyer in the sale and buy with counterfeit certificate object, effective protection is more appropriate given because this dispute has occurred and is being settled in court. A criminal sanction is not yet regulated in Basic Agrarian Law Act, therefore this sanction is based on Article 266, paragraph (1) of the criminal code, which its elements as follows:

Elements whoever;

Elements ordered to enter false information into a Certificate of Authentic;

Elements wear a deed of it as if his statement in accordance with the truth;

Elements of it can cause harm;

Because in the purchase agreement, the elements of Article 266, paragraph (1) of the criminal code have been met then the threat of imprisonment can be given to imprisonment up to 6 years. In addition to administrative sanctions in the form of cancellation of the certificate that is used as the object of sale and purchase in BPN (National Land Agency) and civil sanctions in the form of awarding the compensation described in Section 1246 of the Civil Code, then dressing-a loss that consists of 3 elements, namely:

The cost is the expenditure or costs are real/firm has been issued by the Party.

A loss is a loss due to damage/loss of items and/or property belonging to one of the parties caused by the negligence of the other party.

The flowers, that profits should be obtained/expected by either party if the other party does not negligent in carrying it out.

Because the seller is in breach of the contents of this agreement, then the seller must provide the reimbursement of costs, damages and interest as described in section 1246 of the civil Code. 


\section{CONCLUSIONS}

Based on the results explained above, thus, it can be concluded that 1) legal certainty, the transfer of rights over the land with counterfeit certificate object is the transfer of rights over the land has no legal certainty. In the ruling PN Dps No. 505/Pid.B/2020, seller convicted of a violation of Article 1320 Of the civil code where there is an element of fraud contained in the certificate is in the form of a false statement that put the defendant in a certificate that is not in accordance with the contents of the original and the certificate is not recognized as the proof of ownership of the land so that the elements agreed not met. In addition to that, the seller is considered as a person that is not capable due to not putting the name of the seller in the heirs of the land so that the seller shall not be entitled to sell the land without the permission of the original owners of the land. The legal consequences of such agreements can be requested for cancellation. The implementation of the decision of PN Dps No. 505/Pid.B/2020 is to provide a guarantee to the buyer acting in good faith to obtain legal protection in addition to the presence of this verdict can give the judge a consideration of the judgment against the seller that has the bad faith of this. 2) The legal protection that can be given to the buyer who has a good faith belief type, namely preventive legal protection that can be given is by way of the seller guarantees that certificate is safe from defects and other disorders that result in a loss for the buyer while the repressive legal protection that can be given in the form of sanctions given to the seller namely in the form of criminal sanctions in the form of dungeon which is listed in Article 266 of the criminal code, while the administrative punishment in the form of cancellation of the certificate in the BPN and civil penalties in the form of compensation of all costs incurred by the buyer acting in good faith in accordance with that listed in Section 1246 of the Civil Code. Furthermore, it also can be suggested that 1) in the process of the transfer of rights over the land needs the presence of accuracy not only for buyers but Land Deed Official as the official who certifies the sale and purchase of such land. Land Deed Official should examine first the object used in the sale and purchase agreement that certificate of land. It needs to be done so that later can be aware of the certificate is original or counterfeit, and if there is a falsehood in the certificate of sale that can be cancelled and the buyer acting in good faith can be protected from loss. 2) In the rules of Registration of Land there are rules that protect the buyer from acting in good faith when a certificate is used as the object of sale and purchase is a counterfeit certificate. Should be made about the rule. With the absence of such rules, then the judge can give a fair ruling in the dispute over the sale of land a counterfeit certificate is in addition to the seller to get the prison sentence, he has to replace the loss suffered by the buyer.

\section{REFERENCES}

Adjie, H. (2011). Kebatalan dan Pembatalan Akta Notaris. Jakarta: Refika Aditama.

Agustina, R. (2003). Perbuatan Melawan Hukum. Jakarta: Pascasarjana FH Universitas Indonesia.

Eleanora, F. N., \& Sari, A. (2019). Good Selling Buying Agreement and Legal Protection for Sellers. Lentera Hukum, 6(1), 133. https://doi.org/10.19184/ejlh.v6i1.9833

Hartono, J. A. (2015). Panduan Lengkap Hukum Praktis Kepemilikan Tanah. Surabaya: LaksBang Justitia.

Hernoko, A. Y. (2014). Hukum Perjanjian Asas Proporsionalitas dalam Kontrak Komersial. Jakarta: Kencana.

Muljadi, K., \& Widjaja, G. (2008). Perikatan yang Lahir dari Perjanjian. Jakarta: Raja Grafindo Persada.

Permadi, I. (2016). Perlindungan Hukum terhadap Pembeli Tanah Bersertifikat Ganda dengan Cara Itikad Baik demi Kepastian Hukum. Yustisia Jurnal Hukum, 5(2). https://doi.org/10.20961/ yustisia.v5i2.8762

Prodjodikoro, W. (1993). Asas-asas Hukum Perjanjian. Bandung: Sumur.

Putra, Z. P. B. (2020). The Basics of Good Faith and Good Intention in Land Purchase System in Indonesia. Journal of Law and Legal Reform, 1(4), 29-31. https://doi.org/10.15294/ jllr.v1i4.39782

Rashid, H. Al. (1987). Sekilas tentang Jual Beli Tanah: Berikut Peraturan-Peraturannya. Jakarta: Ghalia Indonesia.

Rijan, Y., \& Koesoemawati, I. (2009). Cara Mudah Membuat Surat Perjanjian/Kontrak dan Surat 
Penting Lainnya. Jakarta: Raih Asa Sukses.

Setiono. (2004). Supremasi Hukum. Surakarta: UNS.

Siahaan, M. P. (2003). Bea Perolehan Hak Atas Tanah dan Bangunan (Cet. 1). Jakarta: Raja Grafindo Persada.

Suparwadi, Munandar, A., \& Putro, W. D. (2020). Legal Protection against Buyer in Good Faith on Dual-Certified Land. International Journal of Multicultural and Multireligious Understanding, 7 (5), 498-505. https://doi.org/http://dx.doi.org/10.18415/ijmmu.v7i5.1717 